JIKAP PGSD: Jurnal Ilmiah Ilmu Kependidikan

Vol,4. No,1. Tahun 2020

e-ISSN: 2597-4440 dan p-ISSN: 2597-4424

(c) (1) This work is licensed under a Creative Commons Attribution

4.0 International License

\title{
Penggunaan Media Modifikasi Bola Plastik Berisi Pasir Untuk Meningkatkan Hasil Belajar Tolak Peluru Penjaskes Siswa Kelas X MIPA 3 SMA Negeri 2 Watampone
}

\author{
Mardiana \\ Sekola Menengat Atas Negeri 2 Watampone, Kabupaten Bone \\ Email: $\underline{\text { mardiana@gmail.com }}$
}

\begin{abstract}
Abstrak: Penelitian ini bertujuan untuk mengetahui peningkatan hasil belajar Tolak peluru Pendidikan Jasmani Olahraga dan Kesehatan melalui penggunaan media modifikasi bola plastik berisi pasir siswa kelas X MIPA 3 SMA Negeri 2 Watampone Kabupaten Bone. Subjek penelitian ini adalah kelas X MIPA 3 SMA Negeri 2 Watampone Kabupaten Bone dengan jumlah siswa 35 orang. Pelaksanaan tindakan dilakukan dalam dua siklus, Data yang terkumpul selanjutnya diolah dengan menggunakan analisis statistik deskriptif kuantitatif dan kualitatif. Secara kualitatif persentase siswa kelas X MIPA 3 SMA Negeri 2 Watampone Kabupaten Bone terlibat secara aktif dalam proses pembelajaran mengalami peningkatan pada semua siswa kelas $\mathrm{X}$ MIPA 3 SMA Negeri 2 Watampone Kabupaten Bone. Dari hasil analisis di atas, maka dapat disimpulkan bahwa dengan menggunakan media modifikasi bola plastik berisi pasir dapat meningkatkan aktivitas proses dan hasil belajar tolak peluru pada siswa kelas X MIPA 3 SMA Negeri 2 Watampone Kabupaten Bone baik secara kuantitatif maupun secara kualitatif.
\end{abstract}

Kata Kunci: Media Modifikasi; Hasil Belajar; Pendidikan Jasmani dan Kesehatan

Abstract. This study aims to determine the increase in learning outcomes Reject bullet Physical Education Sports and Health through the use of plastic ball modification media filled with sand in class X MIPA 3 students of SMA Negeri 2 Watampone Bone Kabupten Bone. The subject of this research is Class X MIPA 3 of SMA Negeri 2 Watampone, Kabupaten Bone with 35 students. The action is carried out in two cycles, the collected data is then processed using quantitative and qualitative descriptive statistical analysis. Qualitatively the percentage of grade X MIPA 3 students in SMA Negeri 2 Watampone Bone District was actively involved in the learning process, increasing in all students of grade X MIPA 3 in SMA Negeri 2 Watampone Kabupaten Bone. From the results of the above analysis, it can be concluded that using modified media of plastic balls containing sand can increase the activity of the process and learning outcomes of shot putting in class X MIPA 3 SMA Negeri 2 Watampone Kabupaten Bone both quantitatively and qualitatively.

Keywords: Modification Media; Learning outcomes; physical education and Health Sciences 


\section{PENDAHULUAN}

Pendidikan jasmani adalah suatu proses pendidikan yang dilakukan secara sadar dan sistematis melalui berbagai kegiatan jasmani dalam rangka memperoleh kemampuan dan keterampilan jasmani, perubahan fisik dan pertumbuhan watak. Aktifitas jasmani yang dimaksud, adalah merupakan kegiatan yang dilakukan oleh siswa untuk meningkatkan keterampilan-keterampilan motorik dan kemampuan yang mencakup aspek kognitif, afektif dan psikomotor, sehingga pendidikan jasmani mulai diterapkan sejak dini mulai dari taman kanak-kanak sampai pada perguruan tinggi, karena pendidikan jasmani adalah media pendorong terhadap keterampilan motorik, kemampuan fisik, pengetahuan dan penalaran serta pembiasaan pola hidup sehat (Slamet, 2010:4).

Tujuan Pendidikan jasmani merupakan penunjang tercapainya tujuan pendidikan nasional. Selain itu, pembelajaran jasmani tidak hanya pembelajaran fisik dan pola hidup sehat saja tetapi terdapat unsur bermain dan olahraga sehingga itu perlu adanya sarana dan prasarana yang dapat menunjang kegiatan pembelajaran. Sarana prasarana merupakan salah satu pendukung dalam pencapaian tujuan pembelajaran. Dengan adanya sarana prasarana, akan dapat mempermudah guru dalam pembelajaran dan pengelolaan kelas maupun lapangan serta menjadikan siswa lebih semangat dan aktif dalam pembelajaran sehingga tujuan pembelajaran akan maksimal. Sebaliknya, jika ketersediaan sarana prasarana yang kurang dan tidak mendukung akan mempersulit kegiatan pembelajaran, sulitnya guru menerapkan materi yang membutuhkan sarana prasarana serta sulitnya siswa menerima materi tanpa sarana prasarana sehingga tidak maksimalnya ketercapainya tujuan pembelajran. Lengkap dan tidak lengkapnya sarana prasarana pembelajaran turut mempengaruhi target-target tujuan pembelajaran.

Keterbatasan sarana atau media pembelajaran banyak ditemui di sekolah-sekolah, salah satunya di SMA Negeri 2 Watampone Kabupaten Bone. Sekolah Menengah Tingkat Atas (SMA) merupakan lembaga pendidikan formal yang memiliki fungsi strategis dalam pengembangan sumber daya manusia. Karena di SMA siswa mendapatkan pengalaman belajar yang tidak sama dengan sekolah yang lainnya. Dengan demikian diperlukan profesionalisme guru yang bertanggung jawab untuk melakukan proses pembelajaran sehingga dapat meningkatkan keberhasilan dalam pembelajaran atletik.

Memodifikasi sarana atau alat pembelajaran pendidikan jasmani merupakan salah satu solusi untuk mengatasi kendala atau kesulitan yang dihadapi siswa dalam pembelajaran Pendidikan Jasmani. Dalam hal ini Rusli Lutan dan Adang Suherman (2000: 75) berpendapat, "Lakukan modifikasi peralatan, apabila peralatan diduga sebagai penghambat keberhasilan". Memodifikasi peralatan dalam pembelajaran pendidikan jasmani sangat penting bagi siswa. Dengan memodifikasi sarana pembelajaran pendidikan jasmani, maka kesulitan atau kendala yang dihadapi siswa dalam pembelajaran pendidikan jasmani dapat teratasi. Contoh dari modifikasi pembelajaran pendidikan jasmani yaitu, pembelajaran lari cepat dengan lari zig zag menggunakan bangku atau kotak, pembelajaran lompat jauh menggunakan kardus atau ban bekas, pembelajaran lompat tinggi dengan menggunakan kardus, pembelajaran tolak peluru menggunakan bola plastik dan lain sebagainya.

Melalui modifikasi peralatan dalam pembelajaran pendidikan jasmani para siswa akan memperoleh suasana atau hal-hal baru. Dengan peralatan yang sederhana dan menarik perhatian siswa, maka dapat membangkitkan motivasi belajar siswa. Pembelajaran yang menarik perhatian siswa, sehingga siswa akan lebih aktif bergerak mengikuti pembelajaran pendidikan jasmani. Jika siswa aktif bergerak dalam mengikuti pembelajaran pendidikan jasmani, maka secara tidak langsung akan meningkatkan kemampuan gerak dasarnya. Apakah benar melalui modifikasi sarana pembelajaran pendidikan jasmani, kemampuan gerak dasar siswa akan meningkat lebih optimal? Untuk membuktikan apakah modifikasi sarana pembelajaran pendidikan jasmani dapat mengoptimalkan kemampuan gerak dasar anak, maka perlu dibuktikan melalui penelitian. Dengan kata lain bahwa sarana pembelajaran juga mempunyai pengaruh besar terhadap keberhasilan pembelajaran.

Sarana prasarana merupakan salah satu bagian yang strategis dalam pencapaian tujuan pembelajaran. Dengan kata lain, lengkap dan tidak lengkapnya sarana prasarana pembelajaran turut mempengaruhi maksimal dan tidak maksimalnya 
ketercapaian tujuan pembelajaran. Sarana yang lengkap bisa memudahkan guru untuk mengejar target-target tertentu yang menjadi tujuan pembelajarannya. Begitu sebaliknya, sarana yang tidak lengkap akan menyulitkan bagi guru dalam mencapai target-target tujuan pembelajarannya. Ini pula yang terjadi pada pembelajaran Tolak Peluru di SMA Negeri 2 Watampone Kabupaten Bone.

Kondisi nyata di sekolah, media peluru hanya tersedia 2 buah, 1peluru untuk putri dan 1 peluru untuk putra. Sementara rata-rata siswa di SMA Negeri 2 Watampone Kabupaten Bone berjumlah 35 - 40 orang, jadi komparasi antara jumlah peluru dan jumlah siswa adalah $1: 20$ putra/putri. Jelas dari gambaran tersebut bahwa proses pembelajaran Tolak Peluru menjadi tidak efektif, dan akibatnya bahwa target kurikulum menjadi sangat rendah. Situasi dan kondisi ini sudah berjalan cukup lama dan sekolah sampai detik ini belum bisa memenuhi sarana peluru tersebut sampai batas yang cukup memadai atau kondisi yang ideal, misalnya dengan perbandingan 1 : 2 ( 1 peluru untuk 2 orang ). Hal ini bisa dimengerti, karena sekolah mempunyai kebutuhan yang sangat banyak dan hampir semuanya mempunyai tingkat urgensitas yang tinggi untuk dipenuhi oleh sekolah. Sehingga menuntut sekolah untuk menyediakan peluru sesuai dengan kondisi ideal, merupakan suatu yang tidak realistis dan lebih jauh bisa menimbulkan gejolak dan iklim yang tidak kondusif di sekolah.

Dari kondisi tersebut proses pembelajaran tolak peluru pada siswa kelas X MIPA 3 SMA Negeri 2 Watampone Kabupaten Bone banyak mengalami permasalahan yang berdampak pada hasil belajar tolak peluru hanya mencapai $32 \%$ dari jumlah siswa 35 siswa, itu diukur dari nilai hasil belajar dengan Kriteria Ketuntasan Minimal (KKM) 70 yang mencapai nilai 70 ke atas hanya 17 Siswa atau 48,57\% sedang sisanya belum tuntas yaitu 18 siswa atau 51,43\%. Oleh karena itu perlu sebuah pemecahan masalah yang sederhana dan bisa dilakukan oleh guru. Melihat permasalahan di atas, maka satu pemikiran yang muncul adalah bahwa perlu adanya sebuah media alternatif modifikatif untuk mengganti peluru, karena siswa dengan alat peluru yang sebenarnya ada yang merasa takut. Media alternatif modifikatif tersebut harus bersifat bisa mewakili karakteristik peluru, murah, banyak tersedia atau mudah di dapat.
Beberapa kriteria media alternatif modifikatif untuk mengganti peluru tersebut nampaknya bola plastik berisi pasir bisa dijadikan media alternatif modifikatif untuk mengganti peluru. Dari segi bentuk, jelas ada kemiripan dengan bentuk peluru, dari segi ketersediaan dan harga, maka bola plastik sangat mudah sekali didapat di pasar-pasar tradisional dengan harga sangat murah. Dari permasalahan tersebut di atas maka penulis menentukan judul Penelitian Tindakan Kelas ini "Penggunaan Media Bola Plastik Untuk Meningkatkan Hasil Belajar Tolak Peluru Siswa Kelas X MIPA 3 SMA Negeri 2 Watampone Kabupaten Bone ".

\section{METODE PENELITIAN}

Penelitian ini adalah penelitian tindakan yang berbasis kelas (class room action research) bertujuan untuk mengungkapkan hasil penelitian sesuai dengan fakta dan data yang diperoleh dilapangan.

Subjek penelitian ini adalah siswa kelas $X$ MIPA 3 SMA Negeri 2 Watampone Kabupaten Bone pada semester genap tahun pelajaran 2015/2016 dengan jumlah siswa 35 orang. Pelaksanaan penelitian ini dilakukan pada bulan Januari-April 2016 yang dimulai minggu II Januari sampai minggu IV April 2016.Penelitian ini berlokasi di SMA Negeri 2 Watampone Kabupaten Bone yang beralamat di Jalan Jenderal Gatot Soebroto No. 1 Kabupaten Bone Provinsi Sulawesi Selatan.

Data yang diperoleh dari hasil pemberian tes, baik pada pelaksanaan tes awal maupun pada akhir pelaksanaan setiap siklus diolah dengan menggunakan statistik deskriptif. Teknik statistik untuk mendeskripsikan karakteristik siswa dan hasilnya disajikan dalam bentuk nilai tertinggi, nilai terendah, nilai rata-rata dan tabel distribusi frekuensi.

Untuk memperoleh tanggapan yang jelas pada pembelajaran tolak peluru Pendidikan Jasmani, Olahraga dan Kesehatan siswa kelas X MIPA 3 SMA Negeri 2 Watampone Kabupaten Bone, dituliskan dengan menggunakan lima kategori yang berpedoman pada sistem penilaian Depdiknas 2006 sebagai berikut:

Table 1: Kategori Penilaian

\begin{tabular}{ll}
\hline Interval Nilai & Kategori \\
\hline $81,0-100$ & Sangat tinggi \\
\hline
\end{tabular}


JIKAP PGSD: Jurnal Ilmiah Ilmu Kependidikan

\begin{tabular}{ll}
\hline $66,0-80,0$ & Tinggi \\
\hline $56,0-65,0$ & Sedang \\
\hline $41,0-55,0$ & Rendah \\
\hline $0-40,0$ & Sangat Rendah \\
\hline
\end{tabular}

\section{HASIL DAN PEMBAHASAN}

Hasil belajar tolak peluru siswa kelas $\mathrm{X}$ MIPA 3 SMA Negeri 2 Watampone Kabupaten Bone setelah pelaksanaan tindakan siklus I melalui penggunaan media modifikasi bola plastik berisi pasir pada pembelajaran tolak peluru. Dari hasil analisis data deskriptif diperoleh rangkuman nilai statistik yang menunjukkan hasil belajar Pendidikan Jasmani, Olahraga dan Kesehatan siswa Kelas X MIPA 3 SMA Negeri 2 Watampone Kabupaten Bone setelah pelaksanaan tindakan siklus I melalui penggunaan media modifikasi bola plastik berisi pasir pada pembelajaran tolak peluru.

Tabel 2:Nilai statistik hasil belajar Pendidikan Jasmani, Olahraga dan Kesehatan melalui penggunaan media modifikasi bola plastik berisi pasir pada pembelajaran tolak peluru siswa Kelas $\mathrm{X}$ MIPA 3 SMA Negeri 2 Watampone
Kabupaten Bone setelah pelaksanaan tindakan pada siklus I.

\begin{tabular}{cc}
\hline Statistik & Nilai Statistik \\
\hline Ukuran sampel & 35 \\
\hline Nilai tertinggi & 80 \\
\hline Nilai terendah & 64 \\
\hline Rentang nilai & 16 \\
\hline Nilai rata-rata & 72,34 \\
\hline
\end{tabular}

Pada tabel 2 menunjukkan bahwa dari 35 siswa Kelas X MIPA 3 SMA Negeri 2 Watampone Kabupaten Bone setelah pelaksanaan tindakan siklus I melalui penggunaan media modifikasi bola plastik berisi pasir pada pembelajaran tolak peluru yang menjadi sampel penelitian ini adalah; nilai tertinggi diperoleh adalah 80 nilai terendah 64 dan rata-rata 72,34. Dari keseluruhan nilai diperoleh siswa jika dikelompokkan dalam lima Kategori, maka distribusi frekuensi dan Kategori hasil belajar tolak peluru Pendidikan Jasmani, Olahraga dan Kesehatan siswa Kelas X MIPA 3 SMA Negeri 2 Watampone Kabupaten Bone setelah pelaksanaan tindakan siklus I melalui penggunaan media modifikasi bola plastik berisi pasir pada pembelajaran tolak peluru pada tabel 3 .

Tabel 3:Distribusi frekuensi persentase dan Kategori hasil belajar tolak peluru Pendidikan Jasmani, Olahraga dan Kesehatan setelah pelaksanaan tindakan melalui penggunaan media modifikasi bola plastik berisi pasir pada pembelajaran tolak peluru siswa Kelas X MIPA 3 SMA Negeri 2 Watampone Kabupaten Bone pada siklus I.

\begin{tabular}{cccccc}
\hline \multirow{2}{*}{ Rentang Nilai } & \multirow{2}{*}{ Kategori } & \multicolumn{2}{c}{ Frekunsi } & \multicolumn{2}{c}{ Persentase } \\
\cline { 2 - 6 } & & Relatif & Kumulatif & Relatif & Kumulatif \\
\hline $\mathbf{0 - 3 4 , 0}$ & Sangat rendah & 0 & 0 & 0 & 0 \\
$\mathbf{3 5 , 0 - 5 4 , 0}$ & Rendah & 0 & 0 & 0 & 0 \\
$\mathbf{5 5 , 0 - 6 4 , 0}$ & Sedang & 6 & 6 & 17,14 & 17,14 \\
$\mathbf{6 5 , 0 - 8 4 , 0}$ & Tinggi & 28 & 34 & 80 & 97,14 \\
$\mathbf{8 5 , 0 - 1 0 0}$ & Sangat tinggi & 1 & 35 & 35 & 100 \\
\hline & Jumlah & $\mathbf{3 5}$ & & $\mathbf{1 0 0}$ & \\
\hline
\end{tabular}

Tabel 3 menunjukkan bahwa dari 35 siswa semua kelas $X$ MIPA 3 SMA Negeri 2 Watampone Kabupaten Bone yang menjadi sampel penelitian $0 \%$ memiliki hasil belajar tolak peluru Pendidikan Jasmani, Olahraga dan Kesehatan dikategorikan sangat rendah, 0\% dikategorikan rendah dan $17,14 \%$ dikategorikan sedang, $80 \%$ dikategorikan tinggi, dan 2,85\% dikategorikan sangat tinggi.
Hasil pengisian lembar observasi dari pengamatan terhadap hasil perilaku siswa Kelas X MIPA 3 SMA Negeri 2 Watampone Kabupaten Bone selama pelaksanaan tindakan siklus I melalui penggunaan media modifikasi bola plastik berisi pasir pada pembelajaran tolak peluru dalam enam kali pertemuan disajikan pada tabel 4. 
Tabel 4: Rata-rata persentase pelaksanaan tindakan pada perilaku yang diamati melalui penggunaan media modifikasi bola plastik berisi pasir pada pembelajaran tolak peluru siswa Kelas X MIPA 3 SMA Negeri 2 Watampone Kabupaten Bone pada siklus I.

\begin{tabular}{cllccc}
\hline No & Komponen yang diperhatikan (diamati) & \multicolumn{2}{c}{ Pertemuan } & \multirow{2}{*}{$\%$} \\
\cline { 3 - 4 } & & $\mathbf{1}$ & $\mathbf{2}$ & \\
\hline 1. & Siswa yang hadir & 30 & 32 & 88,57 \\
\hline 2. & Siswa yang memperhatikan penjelasan guru & 28 & 30 & 82,85 \\
\hline 3. & Siswa yang mengajukan pertanyaan & 12 & 7 & 27,14 \\
\hline 4. & Siswa yang mempresentasikan hasil pekerjaannya & 25 & 29 & 77,14 \\
\hline 5. & Siswa yang dapat menyelesaikan soal dengan benar & 29 & 31 & 85,71 \\
\hline
\end{tabular}

Berdasarkan nilai hasil pemberian tes setelah pelaksanaan tindakan siklus I melalui penggunaan media modifikasi bola plastik berisi pasir pada pembelajaran tolak peluru terlihat bahwa secara umum hasil belajar tolak peluru Pendidikan Jasmani, Olahraga dan Kesehatan siswa Kelas X MIPA 3 SMA Negeri 2 Watampone Kabupaten Bone dikategorikan sedang, hasil pengamatan menunjukkan bahwa masih rendah rata-rata perilaku siswa yang menunjukkan aktivitas mereka dalam melakukan proses belajar mengajar. Selanjutnya berdasarkan hasil siklus II melalui penggunaan media modifikasi bola plastik berisi pasir pada pembelajaran tolak peluru disajikan pada tabel 5

Tabel 5: Nilai statistik hasil belajar Tolak Peluru Pendidikan Jasmani, Olahraga dan Kesehatan setelah pelaksanaan tindakan melalui penggunaan media modifikasi bola plastik berisi pasir pada pembelajaran tolak peluru siswa Kelas X MIPA 3 SMA Negeri 2 Watampone Kabupaten Bone pada siklus II.

\begin{tabular}{cc}
\hline Statistik & Nilai Statistik \\
\hline Ukuran sampel & 35 \\
& \\
\hline Nilai tertinggi & 85 \\
\hline Nilai terendah & 70 \\
\hline Rentang nilai & 15 \\
\hline Nilai rata-rata & 72,34 \\
\hline
\end{tabular}

Pada tabel 4 menunjukkan bahwa dari 35 siswa Kelas X MIPA 3 SMA Negeri 2 Watampone Kabupaten Bone setelah pelaksanaan tindakan siklus II melalui penggunaan media modifikasi bola plastik berisi pasir pada pembelajaran tolak peluru yang menjadi sampel penelitian ini, nilai tertinggi diperoleh adalah 85 , nilai terendah 70 dan rata-rata 77,45. Dari keseluruhan nilai yang diperoleh siswa, jika dikelompokkan dalam lima Kategori, maka distribusi frekuensi persentase dan Kategori nilai hasil belajar Pendidikan Jasmani, Olahraga dan Kesehatan siswa Kelas X MIPA 3 SMA Negeri 2 Watampone Kabupaten Bone setelah pelaksanaan tindakan melalui penggunaan media modifikasi bola plastik berisi pasir pada pembelajaran tolak peluru dapat dilihat pada tabel 6.

Tabel 6: Distribusi frekuensi persentase dan kategori hasil belajar Tolak Peluru Pendidikan Jasmani, Olahraga dan Kesehatan setelah pelaksanaan tindakan melalui penggunaan media modifikasi bola plastik berisi pasir pada pembelajaran tolak peluru siswa Kelas X MIPA 3 SMA Negeri 2 Watampone Kabupaten Bone pada siklus II.

\begin{tabular}{cccccc}
\hline Rentang nilai & Kategori & \multicolumn{2}{c}{ Frekuensi } & \multicolumn{2}{c}{ Persentase } \\
\cline { 3 - 6 } & & Relatif & Kumulatif & Relatif & Kumulatif \\
\hline $0-34,0$ & Sangat rendah & 0 & 0 & 0 & 0 \\
$35,0-54,0$ & Rendah & 0 & 0 & 0 & 0 \\
$55,0-64,0$ & Sedang & 0 & 0 & 0 & 0 \\
$65,0-84,0$ & Tinggi & 26 & 26 & 74,28 & 74,28 \\
$85,0-100$ & Sangat tinggi & 9 & 35 & 25,71 & 100 \\
\hline \multicolumn{7}{c}{ Jumlah } & $\mathbf{3 5}$ & $\mathbf{1 0 0}$ & \\
\hline
\end{tabular}


JIKAP PGSD: Jurnal Ilmiah Ilmu Kependidikan

Tabel 6 menunjukkan bahwa dari 35 siswa semua kelas $\mathrm{X}$ MIPA 3 SMA Negeri 2 Watampone Kabupaten Bone yang menjadi sampel penelitian yaitu tidak ada siswa atau 0\% memiliki hasil belajar tolak peluru Pendidikan Jasmani, Olahraga dan Kesehatan dikategorikan sangat rendah, tidak ada siswa atau $0 \%$ dikategorikan rendah, tidak ada siswa atau 0\% dikategorikan sedang, dan terdapat 26 siswa atau $74,28 \%$ dikategorikan tinggi, dan 9 siswa atau $25,71 \%$ dikategorikan sangat tinggi. Hasil pengisian lembar observasi dari pengamatan terhadap hasil perilaku siswa Kelas X MIPA 3 SMA Negeri 2 Watampone Kabupaten Bone selama pelaksanaan tindakan siklus II melalui penggunaan media modifikasi bola plastik berisi pasir pada pembelajaran tolak peluru dalam dua kali pertemuan disajikan dalam tabel 7. Untuk lebih jelasnya rangkuman rata-rata persentase siswa pada perilaku yang diamati selama dua kali pertemuan disajikan dalam tabel 7 berikut.

Tabel 7: Rata-rata persentase selama pelaksanaan tindakan pada perilaku yang diamati melalui penggunaan media modifikasi bola plastik berisi pasir pada pembelajaran tolak peluru siswa Kelas X MIPA 3 SMA Negeri 2 Watampone Kabupaten Bone pada siklus II.

\begin{tabular}{|c|c|c|c|c|}
\hline \multirow[t]{2}{*}{ No. } & \multirow[t]{2}{*}{ Komponen yang diperhatikan (diamati) } & \multicolumn{2}{|c|}{ Pertemuan } & \multirow[t]{2}{*}{$\%$} \\
\hline & & 3 & 4 & \\
\hline 1. & Siswa yang hadir & 34 & 35 & 98,57 \\
\hline 2. & Siswa yang memperhatikan penjelasan guru & 33 & 35 & 97,14 \\
\hline 3. & Siswa yang menunjukkan pertanyaan & 4 & 2 & 8,57 \\
\hline 4. & Siswa yang mempresentasikan hasil pekerjaannya & 32 & 34 & 94,28 \\
\hline 5. & Siswa yang dapat menyelesaikan soal dengan benar & 32 & 35 & 95,71 \\
\hline
\end{tabular}

Hasil pengisian lembar observasi dari pengamatan terhadap hasil perilaku siswa Kelas X MIPA 3 SMA Negeri 2 Watampone Kabupaten Bone selama pelaksanaan tindakan siklus II melalui penggunaan media modifikasi bola plastik berisi pasir pada pembelajaran tolak peluru terlihat bahwa secara umum hasil belajar tolak peluru siswa Kelas X MIPA 3 SMA Negeri 2 Watampone Kabupaten Bone dikategorikan baik dengan nilai rata-rata 77,45 .

Selanjutnya, berdasarkan hasil pengamatan menunjukkan bahwa rata-rata mengalami peningkatan. Hasil refleksi pelaksanaan tindakan siklus II merupakan hasil akhir dari pelaksanaan penilaian yang telah dilaksanakan melalui penggunaan media modifikasi bola plastik berisi pasir pada pembelajaran tolak peluru. Hasil penelitian ini selanjutnya dilaporkan sebagai bahan rekomendasi.

Dari nilai rata-rata siswa dikategorikan bahwa tingkat pengamatan pembelajaran tolak peluru Pendidikan Jasmani, Olahraga dan Kesehatan siswa Kelas X MIPA 3 SMA Negeri 2 Watampone Kabupaten Bone setelah menggunakan media modifikasi bola plastik berisi pasir pada pembelajaran tolak peluru di Siklus II, berada dalam tingkat penguasaan rendah tidak ada siswa $(0 \%)$, berada dalam tingkat penguasaan sedang tidak ada siswa (0\%), berada dalam tingkat penguasaan yang tinggi 26 siswa $(74,28 \%)$, serta yang berada dalam penguasaan sangat tinggi 9 siswa $(25,71 \%)$. Dengan demikian, dari nilai ratarata siswa setelah menggunakan media modifikasi bola plastik berisi pasir pada pembelajaran tolak peluru dari siklus I dan siklus II terlihat bahwa peningkatan hasil belajar tolak peluru Pendidikan Jasmani, Olahraga dan Kesehatan siswa Kelas X MIPA 3 SMA Negeri 2 Watampone Kabupaten Bone meningkat menjadi kategori baik.

Disamping terjadi peningkatan penguasaan teknik tolak peluru Pendidikan Jasmani, Olahraga dan Kesehatan siswa melalui penggunaan media modifikasi bola plastik berisi pasir pada pembelajaran tolak peluru pada akhir pembelajaran atau dengan kata lain terjadi peningkatan hasil belajar siswa juga ditemukan hal-hal lain yang menunjukkan meningkatnya antusias dan aktivitas kegiatan siswa dalam proses pembelajaran.

Hal-hal lain tersebut dapat disimpulkan sebagai berikut: (1) persentase kehadiran siswa meningkat dari $88,57 \%$ menjadi $98,57 \%$, (2) persentase siswa yang memperhatikan materi 
pelajaran meningkat dari $82,85 \%$ menjadi $97,14 \%$, (3) persentase siswa yang mengajukan pertanyaan tentang tolak peluru yang belum dipahami menurun dari $27,14 \%$ menjadi $8,57 \%$, (4) persentase siswa yang mempresentasikan hasil pekerjaannya meningkat dari $77,14 \%$ menjadi $94,28 \%$ dan (5) mengerjakan soal latihan/menjawab pertanyaan meningkat dari $85,71 \%$ menjadi $95,71 \%$.

Berdasarkan hasil penelitian yang dilakukan, maka peneliti merekomendasikan agar dalam pelaksanaan proses belajar mengajar tolak peluru pada Pendidikan Jasmani, Olahraga dan Kesehatan, guru dapat menggunakan media modifikasi bola plastik berisi pasir pada pembelajaran tolak peluru sebagai pengganti peluru aslinya atau yang sebenarnya. Dengan penggunaan media modifikasi bola plastik berisi pasir pada pembelajaran tolak peluru tersebut, secara kuantitatif dapat meningkatkan hasil belajar tolak peluru dan secara kualitatif dapat meningkatkan aktivitas siswa dalam proses belajar mengajar secara efektif dan efesien.

\section{SIMPULAN DAN SARAN}

Dari hasil analisis data dan pembahasan yang telah dikemukakan sebelumnya, maka dapat disimpulkan bahwa:

1. Secara kuantitatif hasil belajar Pendidikan Jasmani, Olahraga dan Kesehatan pada materi tolak peluru siswa Kelas X MIPA 3 SMA Negeri 2 Watampone Kabupaten Bone setelah pelaksanaan tindakan siklus I melalui penggunaan media modifikasi bola plastik berisi pasir dikategorikan sedang dengan nilai rata-rata 72,34 dan setelah pelaksanaan siklus II dikategorikan baik dengan nilai rata-rata 77,45 .

2. Secara kualitatif, persentase siswa Kelas $X$ MIPA 3 SMA Negeri 2 Watampone Kabupaten Bone yang terlibat secara aktif dalam pelaksanaan proses pembelajaran mengalami peningkatan pada materi tolak peluru siswa Kelas X MIPA 3 SMA Negeri 2 Watampone Kabupaten Bone. Begitu pula setelah pelaksanaan tindakan khususnya pada beberapa orang siswa yang pada pelaksanaan siklus I masih bermasalah khususnya pemahaman dan tingkah laku pada siklus II dapat teratasi dengan baik.

Berdasarkan kesimpulan yang telah dikemukakan di atas, maka peneliti menyarankan:

1. Kepada siswa, disarankan agar dapat mengerjakan tugas yang diberikan karena dapat mengaktifkan siswa di satu sisi serta menjadi informasi bagi guru tentang tingkat pemahaman siswa terhadap materi yang diberikan.

2. Kepada guru pelajaran Pendidikan Jasmani, Olahraga dan Kesehatan, agar dalam setiap pelaksanaan pembelajaran hendaknya dapat memodifikasi alat/media pembelajaran karena media sangat efektif dan dapat meningkatkan pemahaman dan hasil belajar serta aktivitas siswa.

3. Kepada peneliti selanjutnya kiranya dapat mengadakan penelitian lanjutan untuk memperkuat dan mengembangkan hasil penelitian.

\section{DAFTAR RUJUKAN}

Bahagia,Yoyo. 2010. Modifikasi Pembelajaran Pendidikan Jasmani. Jakarta: Fasilitas Perlengkapan Penjas Fakultas Pendidikan Olahraga dan Kesehatan Jurusan Pendidikan Olahraga Universitas Negeri Jakarta.

Depdiknas. 2006. Panduan Pengembangan Silabus Mata Pelajaran Pendidikan Jasmani. BSNP. Jakarta: Depatermen Pendidikan Nasional.

Djumidar. 2001. Dasar-dasar Atletik:1-12,. PPDO2101/4. Cet.3. Jakarta: Pusat Penerbitan Universitas Terbuka Depdiknas.

Edy dan Slamet. 2010. Pendidikan Jasmani Olahraga dan Kesehata untuk SMA Kelas X. Jakarta: Pusat Perbukuan, Kementerian pendidikan Nasional.

Jarver, Jess. 2007. Belajar dan Berlatih Atletik. Bandung: Pioner Jaya.

Nana Sudjana, 2009. Dasar-Dasar Proses Belajar Mengajar. Bandung: Sinar Baru Algensindo.

Poerwodarminto. 2002. Kamus Besar Bahasa Indonesia. Jakarta: Balai Pustaka.

Rusli Lutan, 1988. Belajar Keterampilan Motorik, Pengantar Teori dan Metode. Jakarta: Departemen P\&K Dirjen Dikti Proyek 
JIKAP PGSD: Jurnal Ilmiah Ilmu Kependidikan

Pengembangan Lembaga Pendidikan dan Tenaga Kependidikan.

Rusli Lutan dan Adang Suherman. 2000. Perencanaan Pembelajaran Penjaskes. Jakarta: Depdiknas. Direktorat Jenderal Pendidikan Dasar dan Menengah Bagian Proyek Penataran Guru SLTP Setara D-III.

Saputra, Y.M., 2001. Dasar-Dasar Keterampilan Atletik: Pendekatan secara Profesional. Jakarta: PT. Elex Media Komputindo Kelompok Gramedia.

Slamet. 2010. Pendidikan Jasmani Olahraga dan Kesehatan untuk SMA Kelas X. Jakarta: Pusat Perbukuan, Kementerian pendidikan Nasional.

Soekatamsi dan Srihati Waryati. 1996. Prasarana dan Sarana Olahraga. Surakarta: UNS Press.

Soepartono.1999/2000. Sarana dan Prasarana Olah raga. Departemen Pendidikan Dasar dan Menengah Bagian Proyek Penataran Guru SLTA Setara DIII.

Subagiyo, dkk. 2005. Perencanaan Pembelajaran Pendidikan Jasmani dan Kesehatan. Jakarta: Universitas Terbuka.

Sudjana, Nana dkk. 2009. Penelitian dan Penilaian Pendidikan. Bandung. Sinar Baru Algensindo.

Sukintaka. 2004. Fisiologi Pembelajaran dan Masa Depan Pendidikan Jasmani. Bandung: Yayasan Nuansa Cendekia.

Suyatno. 2010. Pendidikan Jasmani Olahraga dan Kesehatan untuk SMA. Perbukuan Kementerian Pendidikan Nasional Th.2010.

Zainal Aqib, 2009. Penelitian Tindakan Kelas. Bandung: Yrama Widya. 